"This is the peer reviewed version of the following article: [British Journal of Management, 2021] which has been published in final form at [https://onlinelibrary.wiley.com/doi/10.1111/1467-8551.12466] purposes in accordance with Wiley Terms and Conditions for Self-Archiving." 
Submission to British Journal of Management, 2021, Special Issue - Corporate Governance in Extreme Institutional Environments

Manuscript Title: Stewardship Codes and the Role of Institutional Investors in Corporate Governance: An International Comparison and Typology

Author: Alice Klettner

Institution: UTS Business School, University of Technology Sydney

Address: PO Box 123, Broadway, NSW 2007, Australia

Email: alice.klettner@uts.edu.au

Biography: Dr Alice Klettner is a Senior Lecturer in the UTS Business School where she teaches corporate governance and business law. Her research centres around corporate governance regulation and its impact on organisational behaviour. Research interests include the role and responsibilities of boards of directors, regulation of corporate sustainability and gender diversity in leadership.

Web: $\underline{\text { https://profiles.uts.edu.au/Alice.Klettner }}$

Acknowledgements: Thank you to colleagues in the UTS Business school who provided early feedback on this paper and to Karen Nejad for providing invaluable research assistance. Also to the anonymous reviewers who helped greatly in developing the paper for publication. 


\section{Stewardship Codes and the Role of Institutional Investors in Corporate Governance: An International Comparison and Typology}

\section{Abstract}

Over recent decades share-ownership of listed companies has concentrated into the hands of large institutional investors, challenging the traditional agency theory view of corporate governance as a mechanism to resolve the separation of ownership and control. Alternative theories have emerged to explain the role of institutional investors in corporate governance, each with a slightly different view on the motivations of these powerful shareholders and the nature of their relationship with corporate management. These theories share a common thread - the concept of investor stewardship - yet each theory applies it differently. This paper explores whether institutional investors should act primarily as stewards of their investee companies (agency theory), stewards of beneficiaries' funds (agency capitalism), stewards of a market/economy (universal ownership) or stewards of society (stakeholder theory) and whether this varies internationally. Through an analysis of national stewardship codes, the paper determines which of these theoretical approaches are most strongly reflected in emerging stewardship policy across the world. It presents a typology of stewardship codes as a framework for understanding cross-country variation in investor stewardship policy. Stewardship codes influence the shareholder-manager relationship and can encourage integration of wider economic and societal concerns into corporate finance.

\section{Introduction}

The nature of share ownership has gone through significant changes over recent decades (De la Cruz et al., 2019; Fichtner et al., 2017; Hawley and Lukomnik, 2018; Kahle and Stulz, 2017). The majority of listed shares have gone from being owned directly by individuals to being owned by large institutions such as pension funds, mutual funds, insurance companies and unit trusts (Bebchuk et al., 2017; Davis, 2008; De la Cruz et al., 2019; Jahnke, 2019; Ryan and Schneider, 2003). At the end of 2017 , institutional investors held $41 \%$ of global market capitalisation (De la Cruz et al., 2019). Not 
only are stock markets dominated by institutional investors they are dominated by foreign institutional investors. Figures released by the British Office of National Statistics show that in 2018 approximately $54.9 \%$ of UK listed shares were owned by foreign investors (mostly institutional investors) and approximately $31.6 \%$ by domestic institutional investors (Office for National Statistics, 2020). These trends are not limited to Anglo-American corporate governance systems with most OECD countries showing an increase in inward foreign investment into equity markets over recent years (OECD, 2020). Overall there has been a huge concentration of share ownership into the hands of large globally-oriented institutional investors of the likes of Blackrock, State Street and Vanguard (Fichtner et al., 2017; Jahnke, 2019; Schmalz, 2018).

The implications of these share ownership changes for models of corporate governance are underresearched and poorly understood (Barker and Chiu, 2017; Gillan and Starks, 2003; Ryan and Schneider, 2003). There is growing agreement that theories based on the Berle and Means concept of the separation of ownership and control in modern corporations (dispersed shareholders lacking power over their investments) are no longer as accurate or as helpful as they may have been 50 years ago (Berle and Means, 1932; Fichtner et al., 2017; Gilson and Gordon, 2013). The shareholdermanager relationship, although still based on agency, has changed significantly in terms of power relations and investment motivations. As the OECD stated in 2011, "the old question of shareholder oversight of company boards needs to be re-examined in this new context" (OECD, 2011: 10).

It is time to re-think the role of the shareholder in corporate governance in light of both this reconcentration of share ownership and also the growing variation amongst shareholders and their investment strategies (Çelik and Isaksson, 2014; Ryan and Schneider, 2003). The shareholders of a publicly listed company, even those within the institutional investors category, are a heterogeneous and constantly changing group of investors with diverse motives, each providing different challenges for corporate governance (Aguilera et al., 2016; McCahery et al., 2016; McNulty and Nordberg, 2016; Ryan and Schneider, 2003). Importantly, many shares are no longer held directly but are placed with 
asset managers who act on behalf of the institutional investor to manage a portfolio of investments using a variety of different strategies (Hawley and Lukomnik, 2018; Jahnke, 2019).

Thus, institutional investors have been found to behave both as watchdogs or enforcers of good corporate governance, using 'voice' to influence corporate behaviour; yet also as uninterested shortterm traders using 'exit' strategies to increase portfolio value (Edmans and Manso, 2011; Hendry et al. 2006; Hirschman, 1970; Tilba and McNulty, 2013; Tricker, 1998). Research explaining this variation in behaviour and its impact on corporate management, is still in the early stages of development within the corporate governance literature (Fichtner et al., 2017; Goranova et al., 2010; Johnson et al., 2010; McCahery et al., 2016; McNulty and Nordberg, 2016; Ryan and Schneider, 2002; Stathopoulos and Voulgaris, 2016; Tilba and McNulty, 2013). New research questions and theories are emerging around the role of institutional investors in corporate governance. In what circumstances do they act as responsible long-term owners of shares or shortterm traders? (Jahnke, 2019; Otsuka, 2018; Tilba and McNulty, 2013) Have they become so large and powerful to be seen as universal co-owners of the wider economy, (Hawley and Williams, 2002; Schmalz, 2018) or must they act as fiduciaries of specific assets (Sandberg, 2011)?

While academics explore these issues, policy-makers worldwide are encouraging a role for institutional investors as responsible stewards through the introduction of stewardship codes. Stewardship codes are industry-led, soft regulation, directed at institutional investors and intended to resolve some of the tensions that the current situation presents (Cheffins, 2010). As policy documents created by multi-stakeholder groups, stewardship codes are not only instrumentally rational (tools to achieve certain results) but are also expressive of meaning, including individual and collective identity (Yanow, 2000). This makes them worthy of study as a new and fast-developing element of the institutional framework for corporate governance.

Indeed, since the publication of the UK Stewardship Code in 2010, almost twenty other countries have published similar documents and it is highly likely that these stewardship codes will continue to 
proliferate across the globe much like corporate governance codes have since the 1990s (Aguilera and Cuervo-Cazurra, 2009; Cuomo et al., 2016; Hill, 2017). Corporate governance codes have shaped the role of the board of directors over the last twenty years, (Aguilera, 2005; Haxhi and Aguilera, 2012) and stewardship codes will likely do the same for the role of institutional investors.

This paper aims to identify the collective interpretations of stewardship codes regarding the role of institutional investors, as well as any differences in interpretation. It explores which theoretical approaches are most strongly reflected in investor stewardship policy and how this varies across countries. As will be explored below, different corporate governance theories place different relationships at the core of stewardship. Should investors act primarily as stewards of investee corporations (agency theory); stewards of beneficiaries' funds (agency capitalism theory); stewards of a market or economy (universal ownership theory); or stewards of society (stakeholder theory)?

The paper is structured as follows. First it reviews the literature on stewardship codes, comparative corporate governance and the role of institutional investors in corporate governance. Due to the nature of the topic, the review is multidisciplinary incorporating scholarly work across the disciplines of management, law and finance. It compares four theories (agency theory, agency capitalism, universal ownership and stakeholder theory) in terms of their implications for stewardship behaviour on the part of institutional investors. The next section presents the research methodology and findings based on qualitative analysis of nineteen national stewardship codes. The paper draws out commonalities amongst stewardship codes as well as cross-country differences. It presents a typology of stewardship codes based on their dominant theoretical underpinnings. Lastly, it makes suggestions for future research and draws out implications for management practice.

\section{Stewardship codes and comparative corporate governance}

The literature on stewardship codes (as opposed to corporate governance codes more generally) is small, recent and found primarily in the discipline of law. Legal scholars have been interested in the regulatory nature of stewardship codes and whether they are likely to be effective (Cheffins, 2010; 
Chiu, 2013; Hill, 2017; Klettner, 2017; Micheler, 2013; Reisberg, 2015; Roach, 2011; Wheeler, 2013). Early papers focused on the UK Stewardship Code, as the first of its kind. The code was introduced as part of corporate governance reforms recommended after the global financial crisis of 2008. Institutional investors were identified as culprits, 'absentee landlords' failing to do anything to monitor or control wayward executives, particularly in the finance sector (Cheffins, 2010: 1009; Roach, 2011). The majority of scholars have been sceptical about the ability of stewardship codes to trigger significant changes in investor behaviour (Cheffins, 2010; Chiu, 2013; Reisberg, 2015; Roach, 2011). Most considered the initial UK code to be weak due to its limited coverage, (Cheffins, 2010); lack of enforceability (Reisberg, 2015); and the fact that it ignored many of the well know practical barriers to shareholder engagement (Chiu, 2013; Reisberg, 2015). Despite these limitations, several scholars still conclude that stewardship codes have normative power and provide helpful foundations for change (Arsalidou, 2012; Chiu and Katelouzou, 2016). Following the UK's lead, many more countries have now adopted stewardship codes and this has permitted the emergence of early international comparative work in the literature. This work examines the different narratives behind shareholder engagement across different countries and how these differences may impact on code effectiveness (Goto, 2018; Hill, 2017; Klettner, 2017).

In the management literature, the emergence of stewardship codes has been noted within the broader literature on corporate governance codes (Cuomo et al., 2016). In contrast to the legal literature, the management literature does not focus on the implementation and effectiveness of codes but on trying to explain the reasons for code diffusion and variation, their implications for firm performance and whether they provide evidence of convergence of corporate governance towards a common model (Cuomo et al., 2016; Haxhi and Aguilera, 2012; Haxhi and Van Ees, 2010). This paper joins the small number of studies that perform a comparative analysis of the content of different codes in order to better understand specific corporate governance mechanisms. For example, Collier and Zaman (2005a) compare the audit committee concept across 20 European codes; Cicon et al (2012) conduct a thematic analysis of the corporate governance codes of 23 European countries; 
and Zattoni and Cuomo (2010) review the definition of an independent director across 44 codes.

This paper conducts an analysis of 19 stewardship codes to explore the modern role of institutional investors in corporate governance and to compare its dominant theoretical underpinnings across countries.

\section{Stewardship codes and the role of institutional investors}

Moving away from the international comparative literature, stewardship codes have been noted by scholars studying the role of institutional investors in corporate governance, shareholder activism and different forms of corporate ownership (Aggarwal et al., 2011; McNulty and Nordberg, 2016). Theories about the role of investors in corporate governance, particularly institutional investors, are much less developed than those that look at the role of the board (Aguilera et al., 2015). Indeed, other than recognising minority and majority stakes, legal models of corporate governance do not tend to distinguish between different types of investors, treating them all as shareholders with equal rights to participate in corporate governance but no responsibilities (Micheler, 2013). This paper explores the role of institutional investors as explained by four theories: agency theory, agency capitalism, universal ownership and stakeholder theory. As outlined below, each theory predicts different incentives for investors, different responsibilities in corporate governance and therefore different behavioural outcomes in terms of the shareholder-manager relationship. These theories provide the conceptual framework for subsequent analysis of stewardship codes.

Of course, stewardship theory must also be relevant when the word stewardship is so prominent in most stewardship codes. Stewardship is defined by Hernandez as 'the extent to which an individual willingly subjugates his or her personal interests to act in protection of others' (Hernandez, 2008). In corporate governance, stewardship theory has traditionally been applied the managerial level to provide an alternative view to agency theory on the motivations of managers, arguing that they do not always act in a self-interested way, instead, many managers pursue collective benefit (Davis et al., 1997). However, when applying this theory to institutional investors it is possible to take several 
different approaches which align with the other four theories above. As will be explored further below, the theoretical question becomes, to whom should institutional investors act as stewards? Are they expected to be stewards of their investee companies (agency theory); stewards of fund beneficiaries (agency capitalism); stewards of the wider economy (universal ownership); or of all interested stakeholders (stakeholder theory)? It is perhaps the inherent conflicts in trying to act as stewards to all of these different parties that create practical tensions for institutional investors with regard to their role in corporate governance.

\section{Agency theory and agency capitalism}

Agency theory has been highly influential in understanding the shareholder-manager relationship as one of principal and agent (Fama and Jensen, 1983; Jensen and Meckling, 1976). Agency theory tends to treat shareholders as a homogenous group interested in monitoring corporate management, through the board of directors, to ensure their financial interests are met (Gillan and Starks, 2003). In this sense, they can be seen as willing stewards of the company who elect a board to help them monitor and control management to enhance corporate value for all shareholders. They implement stewardship through monitoring corporate performance, engaging with the board and voting at meetings (Bebchuk et al., 2017). Yet empirical findings on the monitoring role of investors is somewhat mixed, "the incentive to monitor and the effectiveness of monitoring varies within the institutional investor community" (Gillan and Starks, 2003: 7). Keay found that most investors do not tend to monitor or engage on a regular basis, only sometimes as a reaction to unusually poor performance (Keay, 2014). This is because the cost of closely monitoring a huge portfolio of shares is high and investors may find it more efficient to reduce risk by selling lowperforming shares: the strategy of 'exit' rather than 'voice' (Hirschman, 1970; McNulty and Nordberg, 2016; Otsuka, 2018). Indeed, a trading mentality rather than an owner mentality has been found to prevail amongst the large majority of institutional investors (Hendry et al. 2006; McNulty and Nordberg, 2016; Tilba and McNulty, 2013). This trading mentality has been enabled by 
technology and innovation as well as the ongoing financialisation of the economy. In particular, hedge funds, index-funds, securitisation and derivatives markets have changed the nature and purpose of share ownership, creating long investment chains that distance the investor from the equities that underlie their investment (Kay, 2012: 30). The consequences of this new environment are helpfully explained by emerging theories of agency or financier capitalism (Barker and Chiu, 2017; Davis, 2008; Gilson and Gordon, 2013) also known as fiduciary or investor capitalism (Hawley and Williams, 2000b; Useem, 1996).

Agency capitalism recognises that new agency relationships found along the investment chain, for example between institutional investors and their fund beneficiaries, and between asset owners and the asset managers that they employ, may pose more of an agency problem for modern corporate governance than the traditional manager-shareholder relationship (Gilson and Gordon, 2013). In fact, these agency relationships can explain the lack of monitoring of corporate management as they reduce the incentives and competence of investment intermediaries to engage with companies and make them more likely to use exit rather than voice (Barker and Chiu, 2017; Gilson and Gordon, 2013). Agency capitalism places institutional investors primarily as stewards of funds. Thus, to protect and grow those funds, they may choose strategies based on modern portfolio theory rather than active ownership of individual companies. Figure 1 compares the traditional agency theory model of corporate governance with an extended agency capitalism model. Although traditional agency costs between shareholders and managers have been mitigated through corporate laws that dictate the composition and duties of the board of directors, new agency costs have arisen between the various intermediaries in the investment chain. Some of these are mitigated by trust laws but others will only be regulated through private contracts which can leave considerable room for selfinterested behaviour. 


\section{Figure 1 Agency theory and Agency Capitalism views of investor stewardship}

Agency theory model of key corporate governance relationships
Agency capitalism model of key corporate governance relationships
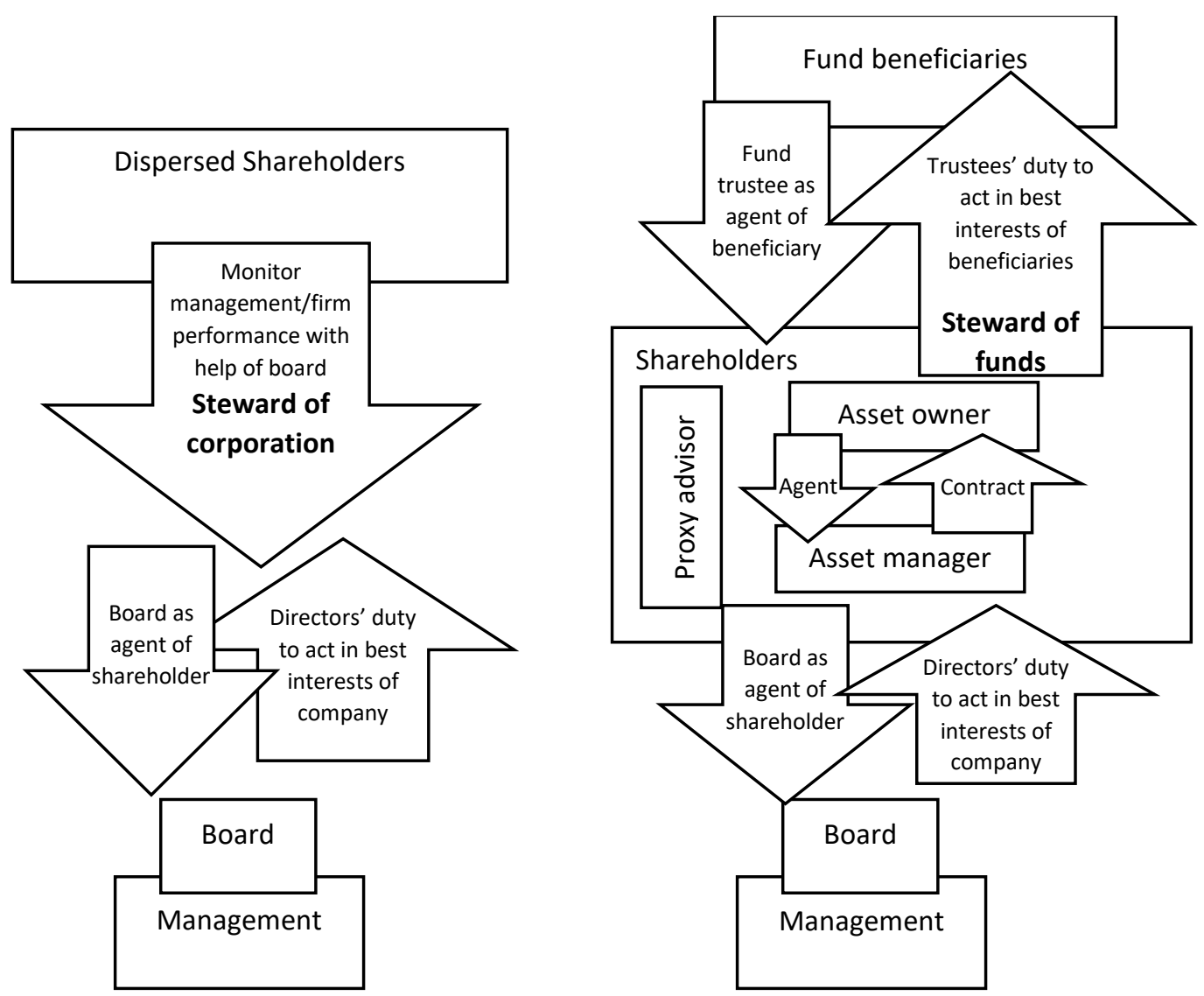

\section{Universal ownership and stakeholder theory}

While agency capitalism takes into account modern investment chains and fiduciary duties, the theory of universal ownership deals specifically with the re-concentration of share ownership into the hands of institutional investors (Hawley and Williams, 2000a). It argues that institutional investors hold such large and diverse portfolios that these holdings represent a cross-section of an entire economy. They cannot escape market impacts by simply selling a few shares and thus they will have a natural interest in 'universal monitoring' (Hawley and Williams, 2002; Juravle and Lewis, 2008; Kiernan, 2007; Lydenberg, 2007). In other words, this theory predicts the opposite of agency capitalism, that these large institutional investors will find it more efficient to reduce risk by using 
the strategy of 'voice' rather than 'exit'. Indeed, the popularity of index investing, where investors commit to investing across an index, may actually prevent investors from using the strategy of exit and provide further incentive for universal monitoring. Universal ownership theory predicts investors will find advantages in acting collectively as this increases their voice (Bebchuk et al., 2017). It suggests that large institutional investors can be seen as stewards of a market or economy rather than of individual companies or funds. They may be more likely to focus their engagement around a particular economic issue than a particular company. In a recent volume of this journal, Mees and Smith provide evidence of this re-concentration of shareholder power through industry associations that mediate collective action to influence the governance practices of investee companies (Mees and Smith, 2019). Mees and Smith also find that institutional investors have been increasingly exercising 'voice' not only around corporate financial performance and corporate governance but around issues of corporate responsibility or sustainability, also known as ESG (environmental, social and governance) factors (Kiernan, 2007; Mees and Smith, 2019: 82). The idea that corporations should be more socially responsible, by balancing the interests of all of their stakeholders (including employees, suppliers, customers and the environment) rather than focusing on the wealth of shareholders, has been embraced both theoretically (Freeman et al., 2004) and, to some extent, in corporate law (Keay, 2010; Keay, 2011). Stakeholder theory, applied primarily to corporate decision-making, now has a parallel at the investor level. As companies increasingly take account of environmental and social issues to demonstrate corporate social responsibility (CSR) or corporate sustainability, institutional investors increasingly take account of ESG factors to demonstrate responsible or sustainable investing (Katelouzou and Klettner, 2020; Majoch et al., 2017; Sparkes and Cowton, 2004) thereby supporting companies' CSR efforts. Paradoxically, stakeholder theory, applied at the investor level, suggests that it is in the interests of shareholders, not to prioritise their own immediate financial interests, but to look to the long term and take an 'enlightened' view of shareholder value when making investment decisions, particularly when they are investing on behalf of others (Keay, 2011; Sandberg, 2011; Sandberg, 2013). In this 
scenario we might see investors as stewards of society, encouraging companies to balance the interests of a variety of stakeholders. Figure 2 demonstrates the way in which these two additional theories subtly alter the model of corporate governance by bringing in wider systemic or social concerns.

\section{Figure 2 Universal ownership and Stakeholder theory views of investor stewardship}

\section{Universal ownership model of key \\ corporate governance relationships}

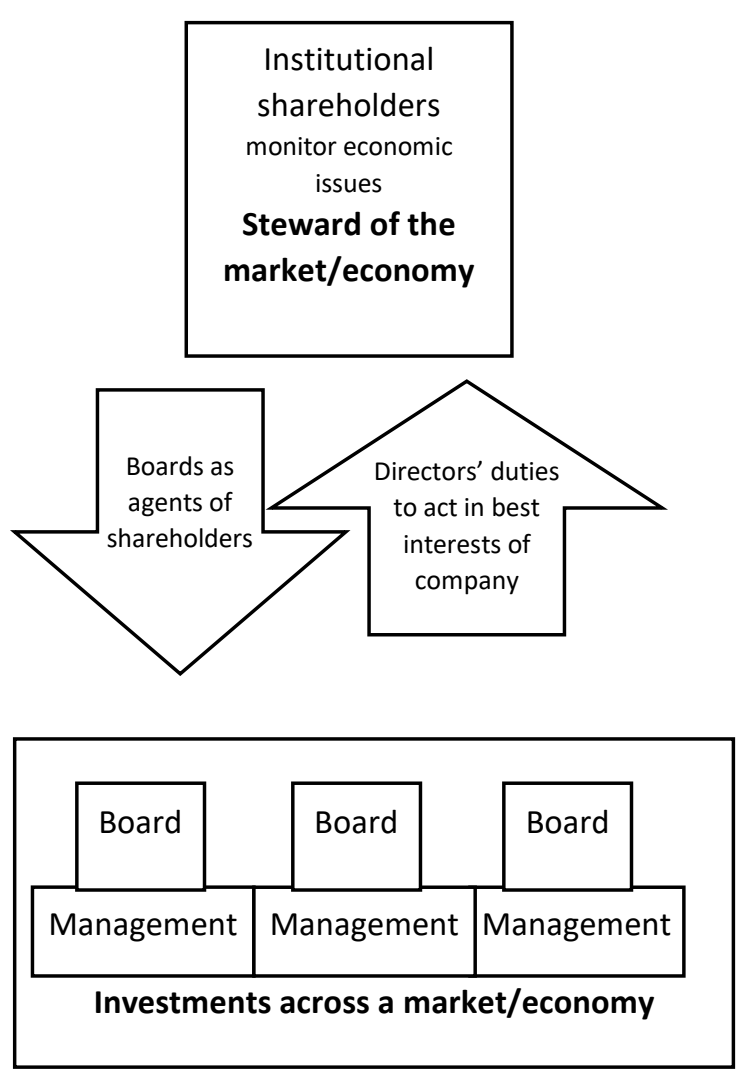

Stakeholder theory model of key corporate governance relationships

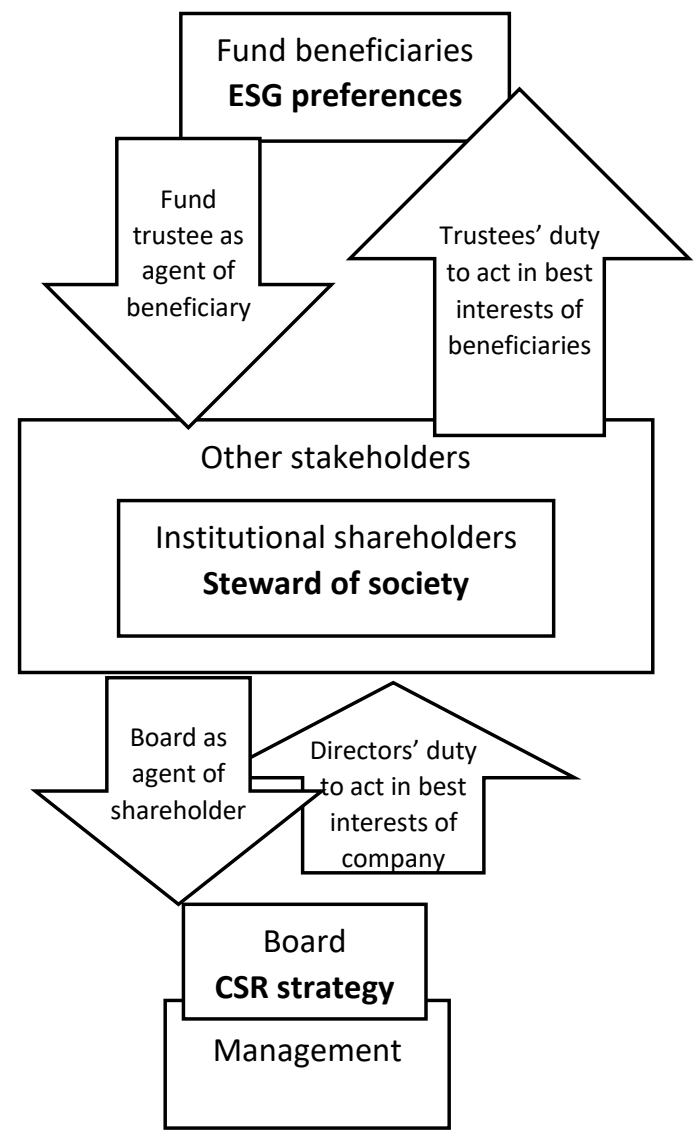

\section{Research design and methodology}

Bearing in mind these potentially conflicting theoretical explanations of the role of institutional investors in corporate governance and their consequences for the meaning of investor stewardship, this paper's objective is to investigate the practical approach recommended by policy-makers, as evidenced in stewardship codes. How do the drafters of stewardship codes (multi-stakeholder 
groups from both industry and government) understand, frame and deal with current tensions in corporate governance theory and practice? The research undertaken is interpretive and qualitative in nature, seeking to discover collective frames of reference that guide the way industry stakeholders interpret the reality they inhabit (Isabella, 1990; Jamali et al., 2008). Framing is a process often discussed in relation to public policy whereby actors impose a particular frame of reference on an issue through careful choice of language, labels and story-telling (Benford and Snow, 2000; Daviter, 2007; Klüver et al., 2015). Stewardship codes, as soft law documents, represent a collective framing process by a mixed group of actors. By analysing the intentions of these quasipolicy makers the paper aims to provide 'an intelligent basis for discussing and judging conflicting ideas, proposals, and outcomes' (Fischer, 1995: 3). Interpretive approaches to policy analysis focus on the meanings that policies have for a broad range of stakeholders as well as tensions and conflicts in meaning (Yanow, 2000). The tension for institutional investors is whether to act as a steward of investee companies, a steward of beneficiaries' funds, a steward of the economy or a steward of wider society. Or whether it is possible to find a successful combination of these aims.

The sample of codes analysed for this research comprises all national stewardship codes published in English prior to the start of 2019 and currently in force. For consistency, the database comprised only the most up-to-date versions of national stewardship codes and not regional or model stewardship codes. Codes were included regardless of whether they were published by government, supervisory bodies or industry associations. The final sample comprised nineteen stewardship codes as detailed in Table 1 including two from Australia (directed at different segments of the investment industry). Using the issuer categories introduced by Cicon et al (2012) five codes were issued by government or regulatory authorities; one by a stock exchange; nine were issued by industry or professional associations; three by composite groups (including at least two of the previous groups) and the last by a private investment service provider. Importantly, all stewardship codes were developed with the input of industry experts and none are mandatory in terms of requiring substantive changes to behaviour. Some mandate disclosure of information but this is on a 
'comply or explain' basis meaning that investors are free to explain their non-compliance with code principles of they feel strict compliance is inappropriate.

Table 1 Research sample: stewardship codes in order of first publication

\begin{tabular}{|c|c|c|c|c|c|}
\hline & Country & Code Title & Code Date & Issuer & Mechanism \\
\hline 1. & $\begin{array}{l}\text { United } \\
\text { Kingdom }\end{array}$ & The UK Stewardship Code & $\begin{array}{l}2012 \text { (first } \\
\text { published } \\
\text { 2010) }\end{array}$ & $\begin{array}{l}\text { Financial Reporting Council } \\
\text { (regulator) }\end{array}$ & Comply-or-explain \\
\hline 2. & Canada & $\begin{array}{l}\text { CCGG } \\
\text { Stewardship Principles }\end{array}$ & $\begin{array}{l}2017 \text { (first } \\
\text { published } \\
\text { 2010) }\end{array}$ & $\begin{array}{l}\text { Canadian Coalition for } \\
\text { Good Governance (investor } \\
\text { association) }\end{array}$ & Voluntary \\
\hline 3. & South Africa & $\begin{array}{l}\text { CRISA Code for Responsible } \\
\text { Investing in South Africa } 2011\end{array}$ & 2011 & $\begin{array}{l}\text { Institute of Directors } \\
\text { Southern Africa (directors } \\
\text { association) }\end{array}$ & Apply-or-explain \\
\hline 4. & Netherlands & $\begin{array}{l}\text { Best practices for Engaged } \\
\text { Share Ownership }\end{array}$ & 2011 & $\begin{array}{l}\text { Eumedion (investor } \\
\text { association) }\end{array}$ & Apply-or-explain \\
\hline 5. & Switzerland & $\begin{array}{l}\text { Guidelines for institutional } \\
\text { investors governing the } \\
\text { exercising of participation } \\
\text { rights in public limited } \\
\text { companies }\end{array}$ & 2013 & $\begin{array}{l}\text { Collaboration of investor } \\
\text { associations }\end{array}$ & Comply-or-explain \\
\hline 6. & Japan & $\begin{array}{l}\text { Principles for Responsible } \\
\text { Institutional Investors }\end{array}$ & $\begin{array}{l}2017 \text { (first } \\
\text { published } \\
\text { 2014) }\end{array}$ & $\begin{array}{l}\text { Financial Services Agency } \\
\text { Council of Experts } \\
\text { Concerning the Japanese } \\
\text { Version of the Stewardship } \\
\text { Code (regulator) }\end{array}$ & Comply-or-explain \\
\hline 7. & Malaysia & $\begin{array}{l}\text { Malaysian Code for } \\
\text { Institutional Investors }\end{array}$ & 2014 & $\begin{array}{l}\text { Minority Shareholder } \\
\text { Watchdog Group and } \\
\text { Securities Commission } \\
\text { Malaysia (joint industry- } \\
\text { regulator) }\end{array}$ & Voluntary \\
\hline 8. & Italy & $\begin{array}{l}\text { Italian Stewardship Principles } \\
\text { for the exercise of } \\
\text { administrative and voting } \\
\text { rights in listed companies }\end{array}$ & $\begin{array}{l}2016 \text { (first } \\
\text { published } \\
2015 \text { ) }\end{array}$ & $\begin{array}{l}\text { Assogestioni (investor } \\
\text { association) }\end{array}$ & Comply-or-explain \\
\hline 9. & Kenya & $\begin{array}{l}\text { Stewardship Code for } \\
\text { Institutional Investors }\end{array}$ & 2015 & $\begin{array}{l}\text { Capital Markets Authority } \\
\text { (regulator) }\end{array}$ & Apply-or-explain \\
\hline 10. & Hong Kong & $\begin{array}{l}\text { Principles of Responsible } \\
\text { Ownership }\end{array}$ & 2016 & $\begin{array}{l}\text { Securities and Futures } \\
\text { Commission (regulator) }\end{array}$ & Voluntary \\
\hline 11. & Taiwan & $\begin{array}{l}\text { Stewardship Principles for } \\
\text { Institutional Investors }\end{array}$ & 2016 & $\begin{array}{l}\text { Taiwan Stock Exchange } \\
\text { (market operator) }\end{array}$ & Comply-or-explain \\
\hline 12. & Brazil & AMEC Stewardship Code & 2016 & $\begin{array}{l}\text { Association of Capital } \\
\text { Markets Investors (industry } \\
\text { association) }\end{array}$ & Voluntary \\
\hline 13. & Denmark & Stewardship Code & 2016 & $\begin{array}{l}\text { The Committee on } \\
\text { Corporate Governance } \\
\text { (expert committee } \\
\text { requested by government) }\end{array}$ & Comply-or-explain \\
\hline 14. & Singapore & $\begin{array}{l}\text { Singapore Stewardship } \\
\text { Principles for Responsible } \\
\text { Investors }\end{array}$ & 2016 & $\begin{array}{l}\text { Stewardship Asia (expert } \\
\text { group) }\end{array}$ & Voluntary \\
\hline 15. & South Korea & KCGS Stewardship Code & 2016 & $\begin{array}{l}\text { Korean Corporate } \\
\text { Governance Service (expert } \\
\text { service provider) }\end{array}$ & Voluntary \\
\hline 16. & $\begin{array}{l}\text { United } \\
\text { States }\end{array}$ & $\begin{array}{l}\text { ISG Stewardship Framework } \\
\text { for Institutional Investors }\end{array}$ & 2017 & $\begin{array}{l}\text { Investor Stewardship Group } \\
\text { (investor association) }\end{array}$ & Voluntary \\
\hline
\end{tabular}




\begin{tabular}{|c|l|l|l|l|l|}
\hline 17. & Thailand & $\begin{array}{l}\text { SEC Investment Governance } \\
\text { Code for Institutional } \\
\text { Investors }\end{array}$ & 2017 & $\begin{array}{l}\text { Securities and Exchange } \\
\text { Commission (regulator) }\end{array}$ & Comply-or-explain \\
\hline 18. & $\begin{array}{l}\text { Australia } \\
\text { FSC }\end{array}$ & $\begin{array}{l}\text { Principles of Internal } \\
\text { Governance and Asset } \\
\text { Stewardship }\end{array}$ & 2017 & $\begin{array}{l}\text { Financial Services Council } \\
\text { (FSC) (investor association) }\end{array}$ & $\begin{array}{l}\text { Comply or explain } \\
\text { mandatory for } \\
\text { members }\end{array}$ \\
\hline 19. & $\begin{array}{l}\text { Australia } \\
\text { ACSI }\end{array}$ & $\begin{array}{l}\text { Australian Asset Owner } \\
\text { Stewardship Code }\end{array}$ & 2018 & $\begin{array}{l}\text { Australian Council of } \\
\text { Superannuation Investors } \\
\text { (investor association) }\end{array}$ & Voluntary \\
\hline
\end{tabular}

To explore the role of institutional investors promoted by stewardship codes, the text of each code was downloaded and entered into Nvivo, a computer-assisted qualitative data analysis software (CAQDAS) program for analysis. The process of analysis followed common practice for analysing qualitative data including comparing and contrasting content as well as coding the data according to theoretical themes (Schreier, 2013; Tilba and McNulty, 2013). Past studies of corporate governance codes have used a similar methodology (Collier and Zaman, 2005b; Heugens and Otten, 2007;

Zattoni and Cuomo, 2008). The theoretical framework used to code the data is described in Table 2. Based on the literature review, the table summarises the key assumptions of four theories and the corresponding role predicted for institutional investors. The text of all stewardship codes was coded in units of one sentence, identifying all sentences that corresponded with one or more of the four theories. Duplicated text was only counted once (for example, lists of contents were not counted). Sentences were coded on the basis of meaning and not simply on the basis of keywords. Both the author and a research assistant coded the data and any coding differences were resolved through detailed discussion.

Table 2 Theoretical Framework

\begin{tabular}{|c|c|c|}
\hline \multicolumn{3}{|l|}{ Agency theory } \\
\hline Assumptions & $\begin{array}{l}\text { Corresponding role for } \\
\text { institutional investors }\end{array}$ & Coding examples \\
\hline $\begin{array}{l}\text { Agency costs (between } \\
\text { principal-shareholders and } \\
\text { agent-managers) can be } \\
\text { reduced by monitoring and } \\
\text { alignment of interests (Fama } \\
\text { and Jensen, 1983; Ryan and } \\
\text { Schneider, 2003) }\end{array}$ & $\begin{array}{l}\text { Investors act as stewards of the } \\
\text { corporation. } \\
\text { Investors will act as monitors - } \\
\text { ensuring, through the board of } \\
\text { directors \& remuneration } \\
\text { schemes, that company }\end{array}$ & $\begin{array}{l}\text { Sentences referring to monitoring } \\
\text { investee companies, engaging with } \\
\text { companies, enhancing value of } \\
\text { companies, e.g: } \\
\text { 'While the board of directors oversees } \\
\text { management, shareholders have a }\end{array}$ \\
\hline
\end{tabular}




\begin{tabular}{|c|c|c|}
\hline $\begin{array}{l}\text { Outcomes are measured } \\
\text { financially e.g. through } \\
\text { maximising shareholder value } \\
\text { (Clarke, 2014; Ryan and } \\
\text { Schneider, 2003) }\end{array}$ & $\begin{array}{l}\text { management runs the company } \\
\text { in their interests } \\
\text { Those interests are primarily } \\
\text { financial meaning that investors } \\
\text { act to improve firm financial } \\
\text { performance. }\end{array}$ & $\begin{array}{l}\text { significant role in corporate } \\
\text { governance in overseeing that the } \\
\text { board fulfills its responsibilities' } \\
\text { (Canada, p1) } \\
\text { 'Regular interaction with investee } \\
\text { listed issuers can help to protect and } \\
\text { guarantee value in the long-term' } \\
\text { (Italy p16) }\end{array}$ \\
\hline \multicolumn{3}{|l|}{ Agency capitalism } \\
\hline Assumptions & $\begin{array}{l}\text { Corresponding role for } \\
\text { institutional investors }\end{array}$ & Coding examples \\
\hline $\begin{array}{l}\text { Another significant agency } \\
\text { relationship exists between } \\
\text { shareholders and beneficial } \\
\text { owners (Bebchuk et al., 2017; } \\
\text { Gilson and Gordon, 2013) } \\
\text { Business models and } \\
\text { increasingly long investment } \\
\text { chains limit incentives and } \\
\text { capacity to monitor portfolio } \\
\text { companies other than through } \\
\text { share price (Gilson and Gordon, } \\
\text { 2013) }\end{array}$ & $\begin{array}{l}\text { Investors act as stewards of } \\
\text { specific funds. } \\
\text { Most large investors are } \\
\text { fiduciaries taking care of the } \\
\text { funds of beneficiaries } \\
\text { These investors may act as } \\
\text { traders rather than owners } \\
\text { using exit rather than voice to } \\
\text { improve fund financial } \\
\text { performance. }\end{array}$ & $\begin{array}{l}\text { Sentences referring to clients, } \\
\text { beneficiaries, funds, fiduciary duties, } \\
\text { investment chain, outsourcing, } \\
\text { mandates, e.g: } \\
\text { 'An investor investing funds on behalf } \\
\text { of clients has a duty to act in the } \\
\text { interests of its clients and/or the } \\
\text { beneficiaries of the funds provided by } \\
\text { its clients' (Hong Kong p6) } \\
\text { 'The ultimate responsibility for the } \\
\text { exercise of stewardship activities } \\
\text { remains with the investor, regardless } \\
\text { of whether certain activities are } \\
\text { outsourced' (Denmark p 6) }\end{array}$ \\
\hline \multicolumn{3}{|l|}{ Universal ownership } \\
\hline Assumptions & $\begin{array}{l}\text { Corresponding role for } \\
\text { institutional investors }\end{array}$ & Coding examples \\
\hline $\begin{array}{l}\text { Due to their size and dispersed } \\
\text { portfolio of investments, } \\
\text { institutional investors will be } \\
\text { concerned not with individual } \\
\text { company performance but of } \\
\text { the economy/market as a } \\
\text { whole (Hawley and Williams } \\
\text { 2000a; Lydenberg, 2007). } \\
\text { Monitoring costs can be } \\
\text { reduced by investors acting } \\
\text { collaboratively (Bebchuk et al., } \\
\text { 2017) }\end{array}$ & $\begin{array}{l}\text { Investors act as stewards of a } \\
\text { market or economy } \\
\text { Large investors cannot act as } \\
\text { traders as they are invested in } \\
\text { the whole economy and will use } \\
\text { voice rather than exit. } \\
\text { To increase their voice, } \\
\text { institutional investors may act } \\
\text { collaboratively. }\end{array}$ & $\begin{array}{l}\text { Sentences referring to the wider } \\
\text { economy or market, the power and } \\
\text { influence of investors within that } \\
\text { market, including through collective } \\
\text { engagement, e.g: } \\
\text { 'Institutional investors are major } \\
\text { players in the global economy who } \\
\text { can exert significant influence over } \\
\text { their investee companies due to the } \\
\text { substantial stake they hold' (Malaysia, } \\
\text { p3). } \\
\text { It may be appropriate to carry out } \\
\text { collective engagements, for example, } \\
\text { in the case of significant corporate } \\
\text { events or issues of public interest } \\
\text { (such as serious economic or sectoral } \\
\text { crises)' (Italy p 17) }\end{array}$ \\
\hline \multicolumn{3}{|l|}{ Stakeholder theory } \\
\hline Assumptions & $\begin{array}{l}\text { Corresponding role for } \\
\text { institutional investors }\end{array}$ & Coding examples \\
\hline
\end{tabular}


Taking the interests of all stakeholders into account leads to sustainable value creation (Freeman et al., 2004).

Some stakeholders may be more salient than others in their claims on the firm at different times (Mitchell et al., 1997).
Investors act as stewards of society/the planet.

Investors will encourage companies to mediate different stakeholder interests by taking a long-term view of value and incorporating social and environmental factors.

Different types of investors may agitate for specific environmental or social changes.
Sentences referring to stakeholders (other than shareholders), sustainability and ESG issues, e.g:

'It is no longer appropriate for institutional investors to focus on only monetary benefit to the ultimate beneficiaries of investments to the exclusion of factors that impact on long-term sustainability' (South Africa p7)

'Investment decisions should take into consideration the commitment of Investee Companies to ESG principles...' (Thailand p11)

\section{Findings and discussion}

Table 3 reveals that an agency theory interpretation of the role of institutional investors is reflected most strongly across all codes in terms of the collective total number of references (345), with agency capitalism slightly less dominant (330). However, if codes are grouped based on the strongest theory per code (shaded in grey) the opposite is found: there are slightly more codes with agency capitalism as their strongest theme (nine codes) than there are with agency theory as their strongest theme (eight codes). For South Korea the two themes were of equal prominence and the South African code was the only one with a different theory, stakeholder theory, most prominent. The fourth theory, universal ownership, was not heavily reflected in any code, although all codes (except Switzerland) referred at least briefly to the advantages of collective ownership and/or the ability of institutional investors to influence companies and the economy as a whole. Although this theory was not easy to pick up in the specific recommendations of the codes, its theme of using voice (engagement and dialogue) rather than exit (selling shares) is implied in the overall concept of active ownership of shares (McNulty and Nordberg, 2016). 
Table 3 Stewardship codes' interpretation of the role of institutional investors

\begin{tabular}{|c|c|c|c|c|c|c|c|c|c|}
\hline \multirow{2}{*}{$\begin{array}{l}\text { Country } \\
\text { Australia } \\
\text { ACSI }\end{array}$} & \multicolumn{2}{|c|}{ Agency } & \multicolumn{2}{|c|}{$\begin{array}{l}\text { Agency } \\
\text { Capitalism }\end{array}$} & \multicolumn{2}{|c|}{ Stakeholder } & \multicolumn{2}{|c|}{$\begin{array}{l}\text { Universal } \\
\text { Ownership }\end{array}$} & \multirow{2}{*}{$\begin{array}{l}\begin{array}{l}\text { Total refs } \\
\text { per code }\end{array} \\
53 \\
\end{array}$} \\
\hline & 7 & $13 \%$ & 21 & $40 \%$ & 17 & $32 \%$ & 8 & $15 \%$ & \\
\hline Australia FSC & 11 & $35 \%$ & 18 & $58 \%$ & 1 & $3 \%$ & 1 & $3 \%$ & 31 \\
\hline Brazil & 9 & $23 \%$ & 12 & $31 \%$ & 9 & $23 \%$ & 9 & $23 \%$ & 39 \\
\hline Canada & 26 & $42 \%$ & 25 & $40 \%$ & 4 & $6 \%$ & 7 & $11 \%$ & 62 \\
\hline Denmark & 16 & $67 \%$ & 4 & $17 \%$ & 2 & $8 \%$ & 2 & $8 \%$ & 24 \\
\hline Hong Kong & 10 & $32 \%$ & 15 & $48 \%$ & 2 & $6 \%$ & 4 & $13 \%$ & 31 \\
\hline Italy & 27 & $60 \%$ & 12 & $27 \%$ & 2 & $4 \%$ & 4 & $9 \%$ & 45 \\
\hline Japan 2014 & 19 & $49 \%$ & 18 & $46 \%$ & 1 & $3 \%$ & 1 & $3 \%$ & 39 \\
\hline Kenya & 42 & $51 \%$ & 18 & $22 \%$ & 15 & $18 \%$ & 7 & $9 \%$ & 82 \\
\hline Korea & 24 & $48 \%$ & 24 & $48 \%$ & 0 & $0 \%$ & 2 & $4 \%$ & 50 \\
\hline Malaysia & 23 & $34 \%$ & 31 & $46 \%$ & 10 & $15 \%$ & 3 & $4 \%$ & 67 \\
\hline Netherlands & 17 & $50 \%$ & 7 & $21 \%$ & 6 & $18 \%$ & 4 & $12 \%$ & 34 \\
\hline Singapore & 20 & $48 \%$ & 13 & $31 \%$ & 3 & $7 \%$ & 6 & $14 \%$ & 42 \\
\hline South Africa & 14 & $25 \%$ & 15 & $27 \%$ & 23 & $41 \%$ & 4 & $7 \%$ & 56 \\
\hline Switzerland & 6 & $27 \%$ & 15 & $68 \%$ & 1 & $5 \%$ & 0 & $0 \%$ & 22 \\
\hline Taiwan & 15 & $34 \%$ & 25 & $57 \%$ & 1 & $2 \%$ & 3 & $7 \%$ & 44 \\
\hline Thailand & 29 & $38 \%$ & 22 & $29 \%$ & 18 & $24 \%$ & 7 & $9 \%$ & 76 \\
\hline UK 2012 & 21 & $39 \%$ & 24 & $44 \%$ & 1 & $2 \%$ & 8 & $15 \%$ & 54 \\
\hline US & 9 & $41 \%$ & 11 & $50 \%$ & 0 & $0 \%$ & 2 & $9 \%$ & 22 \\
\hline $\begin{array}{l}\text { Collective } \\
\text { Totals per } \\
\text { theory }\end{array}$ & 345 & $40 \%$ & 330 & $38 \%$ & 116 & $13 \%$ & 82 & $9 \%$ & 873 \\
\hline
\end{tabular}

\section{Similarities across codes}

Although initially introduced to deal with the classic agency theory problem of lack of monitoring of corporate management, (Cheffins, 2010; Chiu, 2012a) stewardship codes, as a whole, recognise that new agency problems within the investment chain, explained by agency capitalism theory, (Gilson and Gordon, 2013) also need to be addressed. Stewardship codes show that these two theories can be complementary, rather than conflicting, but that classic agency theory applied to institutional investors does not make practical sense alone: we also need to understand and deal with the modern agency costs inherent in the financial chain from fund beneficiary, to asset owner, through asset managers to the investment in a listed company. Until now corporate governance frameworks have not recognised the importance of these additional relationships to the functioning of the overall system (Bebchuk et al., 2017). 
Of course, these agency relationships within the investment chain have not gone entirely unnoticed. Legal systems have long dealt with the agency relationship between fund beneficiaries and asset owners by imposing fiduciary duties upon fund trustees (Sandberg, 2013). Fiduciary duties recognise the fact that institutional investors are managing money that ultimately belongs to someone else and thus they must place the best interests of the actual owners above their own interests (Sandberg, 2011). Thus many codes place investors primarily as stewards of funds and only indirectly as stewards of corporations. As the Canadian code states, 'Stewardship for institutional investors means fulfilling their responsibilities as fiduciaries in meeting their obligations to beneficiaries or clients'.

Stewardship codes recognise the costs of agency capitalism and attempt to resolve the problem by using investors' legal duties to their clients and beneficiaries as an incentive to monitor both investee companies (in accordance with classic agency theory) and also any financial intermediaries who may otherwise distort or reduce the incentives to monitor. Indeed, stewardship codes have cleverly leveraged these legal duties to encourage monitoring throughout the investment chain. As the Hong Kong code states, 'Owners of company equity should not blindly delegate these responsibilities. Even when they employ agents, directly or indirectly, to act on their behalf, owners should ensure that their ownership responsibilities are appropriately discharged by those agents'. The implications of this extended agency capitalism model of corporate governance for both managerial practice and corporate governance theory are extensive. In theory it places much of civil society (those of us with money in savings or pension funds) in a position to influence corporate governance (Raelin and Bondy, 2013). This is one reason why stakeholder theory has potential to enter the equation. It would seem paradoxical to suggest that investors as shareholders would want to challenge their own primacy in corporate governance. But if those investors are representatives of broader society this begins to make more sense and permits wider stakeholder interests to be considered (Kiernan, 2007). It may permit the return of legal concepts such as fairness, justice and reasonableness into the finance system providing a much needed counter-weight to the recent 
economic focus on rational, efficient value-maximisation (Lydenberg, 2014). Stewardship codes may have the effect of introducing more accountability and public interest into the fulfilment of fiduciary duties (Chiu, 2012b).

\section{Differences across codes}

Table 3 also shows that a stakeholder theory interpretation of the role of institutional investors is dominant in only a small number of codes. Stakeholder theory is reflected more strongly than agency theory in only two codes (South Africa and Australia ACSI) and is equal with agency theory in the Brazilian code. Other codes with above average focus on stakeholder theory and ESG include Thailand, Kenya, the Netherlands and Malaysia. Future research will hopefully further unpack and explain these cross-country differences, perhaps based on institutional factors or varieties of capitalism theories. However, stewardship codes hint that theories of political economy may also provide a helpful lens through which to view differences in countries' approaches to investor stewardship. The introduction to the Malaysian code refers to Malaysia's vision of becoming a highincome nation exhibiting inclusiveness and sustainability whereas the Australian (ACSI) code refers to recent increased demand for sustainable business. It seems that encouraging sustainability can be part of a wider policy objective of attracting foreign investment and/or countering social or environmental problems. For example, South Africa began its focus on responsible investing during the boycotts of the Apartheid years, (Naqvi, 2019) whereas Thailand has been forging ahead with ESG as a way to demonstrate its efforts to curb human trafficking, grow sustainable fisheries and stem corruption (Zembrowski, 2019). The Thailand stock exchange positions good ESG disclosures as a competitive advantage and a way to attract foreign investors and is now ranked number 7 in the world when it comes to sustainability disclosure regimes (Zembrowski, 2019). The Capital Market Authority in Kenya and the Nairobi Securities Exchange recently joined the UN Sustainable Stock Exchanges initiative explaining that they seek to build trust in Kenya and help responsible companies attract investors (SSE, 2019). Theories of political economy might help to explain different policy 
approaches to corporate governance that are not easily related to prevailing corporate governance models or ownership structures (Aguilera and Crespi-Cladera, 2016; Veldman and Willmott, 2016).

Even codes with a high agency theory focus are not silent on wider stakeholders and ESG, they just approach the issue from a different perspective. They place ESG within the large basket of factors that can impact on corporate value. For example the Singapore code considers that to 'meet the aims of long-term value creation, capital efficiency and sustainable growth', investors should 'engage with their investee companies on a full spectrum of topics, including strategy, long-term performance, risk, financials, culture, remuneration, social and environmental considerations and corporate governance'. The Kenyan code states, 'In the investment context, the main focus of institutional investors is on those aspects of social, environmental and ethical practice by issuers that may pose a material commercial risk or opportunity'. These statements can be seen to reflect an 'enlightened shareholder value' view of corporate governance as a way of integrating the economics of agency theory with the social benefits of stakeholder theory (Jensen, 2002; Keay, 2011; Keay, 2012; Queen, 2015).

\section{Typology of stewardship codes}

Table 4 together with Figure 3 suggests a typology of stewardship codes based on the data. The first category in the typology comprises the codes with a high focus on both agency theory and agency capitalism, found in the middle of the graph. This category includes codes in highly developed financial markets: the UK, US, Canada, Hong Kong, South Korea and Japan. It may be that these are countries where the presence of complex investment chains is common, skewing incentives for traditional monitoring of listed companies. These codes are directed at resolving those skewed incentives by recognising and integrating the investment chain into corporate governance monitoring processes. Many of these codes, like those in category two below, are issued by organisations that also publish the country's corporate governance code. In these countries, 
investors are being asked to be stewards of both the companies they invest in and the funds they manage, with stewardship codes focusing on a win-win situation for both.

\section{Table 4: Typology of stewardship codes}

\begin{tabular}{|c|c|}
\hline 1. High Agency and High Agency Capitalism & 2. High Agency, Low Agency Capitalism \\
\hline $\begin{array}{l}\text { UK, US, Canada, Hong Kong, Japan, South Korea, } \\
\text { Malaysia }\end{array}$ & Denmark, Italy, Kenya, Netherlands, Singapore \\
\hline $\begin{array}{l}\text { Progressive view of importance of investment chain } \\
\text { in improving corporate governance } \\
\text { Stewards of both investee companies and } \\
\text { beneficiaries' funds }\end{array}$ & $\begin{array}{l}\text { Traditional view of improving corporate governance } \\
\text { Stewards of investee companies }\end{array}$ \\
\hline 3. Low Agency and High Agency Capitalism, & $\begin{array}{l}\text { 4. Low Agency and Low Agency Capitalism } \\
\text { (High Stakeholder) }\end{array}$ \\
\hline Switzerland, Taiwan, Australia FSC & Australia ACSI, Brazil, South Africa, Thailand \\
\hline $\begin{array}{l}\text { Stewardship codes with a focus on } \\
\text { beneficiaries/clients rather than corporations } \\
\text { Stewards of beneficiaries' funds }\end{array}$ & $\begin{array}{l}\text { Progressive view of fiduciary duties that encourages } \\
\text { incorporation of ESG factors } \\
\text { Stewards of society. }\end{array}$ \\
\hline
\end{tabular}

\section{Figure 3 Typology of stewardship codes}

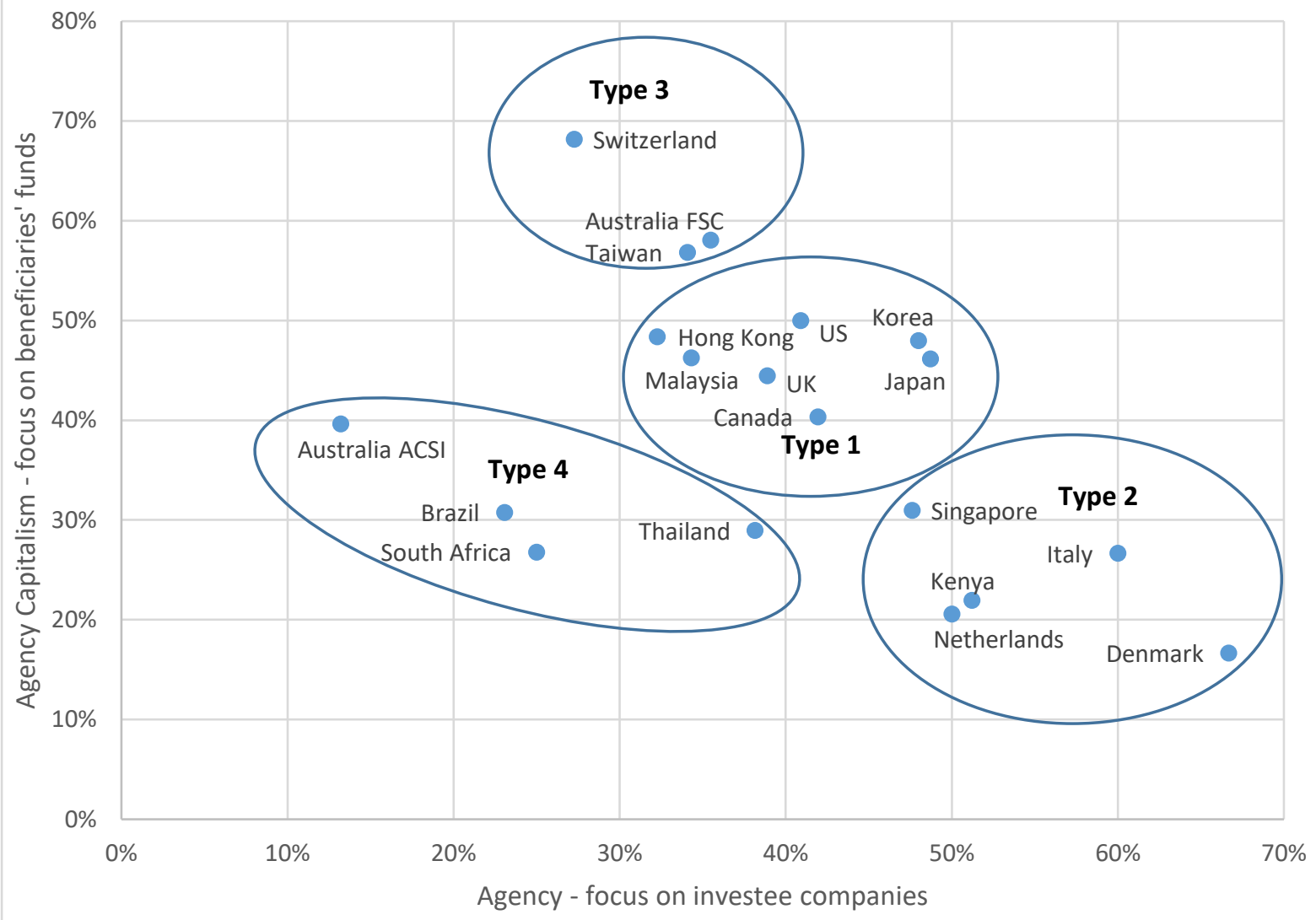


The second category, clustered at the bottom right of the graph, are the codes with a dominant agency theory focus where investors are framed primarily as monitors of corporate performance. These codes focus on the relationship between investors and companies and spend less time exploring agency problems in the investment chain. It is interesting that several of these codes have been introduced as companions to a corporate governance code. For example, the Danish code is issued by the Committee on Corporate Governance and aims to reinforce the Recommendations on Corporate Governance 'to promote the companies' long-term value creation and thereby contribute to maximising long-term return for investors'. The Kenyan code is also partnered closely with the country's code of corporate governance and designed specifically to help in assessing compliance with this code, 'monitoring of this nature is essential if the 'apply or explain' Code of Corporate Governance is to have impact'. Another feature of some of the codes in this category is that they highlight specific governance issues in the local market. For example, the Italian code mentions that 'the presence of independent minority members of the corporate bodies of investee listed issuers can serve as a method of monitoring'. The Kenyan code refers to controlling foreign ownership by multinationals and 'balancing the interests of the global multinational with the interests of minority shareholders'. Thus their focus on investors as governance monitors might be explained by local share ownership patterns and market-specific governance problems. The Dutch code refers to other best practice provisions for institutional investors found in the Dutch corporate governance code. Thus, in a national context, the focus of a stewardship code may be determined by gaps that need to be filled in a wider regulatory framework: if agency relationships and fiduciary duties are dealt with elsewhere, the code may not need to mention them.

Category three, at the top of the graph, includes codes where the focus on agency capitalism is stronger than on agency theory. These include the Australian FSC code, Switzerland and Taiwan. Again, this might be explained by the nature of the issuers of these codes. The Australian FSC code is directed at asset managers only, so focused on participants within the investment chain and aimed at improving the domestic financial services industry, with a strong emphasis on the internal 
governance of asset managers. The Taiwanese code is issued by the stock exchange, so is an organisation very much aware of the realities of the local market. The Swiss code is issued by a collaboration of investor associations. These organisations will be most concerned with investors' fiduciary duties to their clients and beneficiaries.

Lastly, category four comprises the codes, mentioned above, that have the strongest stakeholder theory interpretations of the role of institutional investors. These codes tend to be low on agency theory and relatively low on agency capitalism, yet they do still have something to say on stewardship of beneficiaries' funds. They promote an interpretation of fiduciary duty that encourages a long-term perspective of investment incorporating environmental, social and governance (ESG) factors. For example, the Brazilian code states, 'by carefully managing the assets of their end beneficiaries, institutional investors should consider relevant ESG factors as crucial aspects when it comes to the fulfilment of their fiduciary duty'. It can be argued that they place investors as stewards of wider society and the environment. Indeed, across the world, there has been a long-running debate over the extent to which investors' fiduciary duties permit them to incorporate ESG factors (Richardson 2009; Sandberg 2011; Sandberg 2013). This debate revolves around the meaning of 'the best interests of beneficiaries'. In many jurisdictions this phrase was traditionally interpreted as meaning the best financial interests of beneficiaries and, in some, it was equated to a duty to maximise investment returns. Although this debate has now been mostly resolved to permit the taking into account of ESG factors, (Freshfields Bruckhaus Deringer 2005; PRI 2015) local rules and customs around the scope and interpretation of fiduciary duties could explain differences across countries.

\section{Limitations and future research}

This research studies the content of stewardship codes rather than the antecedents, implementation or outcomes of stewardship codes. Its aim is to advance understanding of the theoretical foundations of the policy of investor stewardship and the way codes endeavour to reconcile 
inherent tensions in the role of institutional investors. Hopefully the typology presented here will provide a framework for future international comparative research exploring the reasons behind national differences. Potential approaches to exploring and explaining cross-country variation might include use of theories of political economy; varieties of capitalism; share ownership structures; code issuer identity; as well as prevailing corporate governance models. The way in which codes recognise and deal with the heterogeneity of investors is also interesting and the theoretical leanings of a code may reflect the predominant type of investor in that market.

There is also great scope for research into the impact of the investment chain on corporate governance and development of the agency capitalism corporate governance model. Transmission of responsible investment mandates, as recommended by stewardship codes, may be effective when the investment chain is relatively simple but will become extremely difficult in circumstances where structured financial products twist the purpose of share ownership into something entirely different. Many codes recognise this limitation, providing loopholes and narrowing the code's influence to those investors already using strategies of long-term ownership. Research that takes into account the heterogeneity of shareholders and their strategies is needed to determine the proportion of any market likely to behave as each of the four types of stewards.

\section{Conclusion}

Significant changes in share ownership over recent years have placed institutional shareholders in a powerful position, altering the dynamics of corporate governance and challenging existing theoretical models. Institutional investors are well placed to engage with corporate leaders and monitor investee companies yet do not always do so, leaving a gap in the market-based enforcement of good governance (Cheffins, 2010; Chiu, 2012a). Stewardship codes provide evidence of the industry response to these contemporary governance problems, attempting to redefine the role of institutional investors in corporate governance. They help us to understand the conflicts faced by institutional investors both in a practical and theoretical sense and how these 
might be resolved. This research explores whether institutional investors should act primarily as stewards of their investee companies (agency theory), stewards of beneficiaries' funds (agency capitalism), stewards of a market/economy (universal ownership) or stewards of society (stakeholder theory). Of course, the answer is that they can try to do all of these things but their primary focus will be directed by local laws, regulation, markets and institutions including the issuers of stewardship codes.

This analysis of stewardship codes across the world reveals collective recognition of the importance of the modern investment chain in corporate governance and the additional agency costs that it creates. To tackle these extended agency costs, stewardship codes draw on the fiduciary duties imposed upon institutional investors, using these as an incentive to monitor and control agents throughout the chain. Thus the role of an institutional investor is primarily as a steward of funds which then indirectly incorporates the role of steward of investee corporations. In other words, to protect and grow their funds, investors must monitor corporate performance. However, some codes veer away from the shareholder-centric view of corporate governance, bringing in elements of stakeholder theory and universal ownership to justify consideration of wider societal or economic concerns over the long-term. This has important implications for management in terms of defining the purpose of the corporation and finding an acceptable balance between the pursuit of shareholder value and the interests of wider stakeholders. Increasing global interest in improving the sustainability of financial systems is only likely to push stewardship codes further towards stakeholder theory concepts and integration of ESG (Katelouzou and Klettner, 2020). Indeed, the 2020 versions of both the UK and Japanese codes have increased emphasis on ESG, possibly altering their position in the typology of codes above. If collective action becomes more commonplace, as it is beginning to in some countries, (Mees and Smith, 2019) we might see institutional investors as stewards of the economy more widely following the theory of universal ownership (Hawley and Williams, 2002). As a whole, stewardship codes try to balance the tensions inherent in the role of institutional investors, encouraging them to consider long-term corporate purpose using 
collaborative engagement rather than pursuit of short-term shareholder value through competitive trading.

Capital markets and the investment industry have changed significantly over recent decades and governance theory and institutional frameworks are struggling to catch up. We may be on the verge of a new paradigm for corporate governance involving a system-wide perspective, (Hawley and Lukomnik, 2018); integration of corporate sustainability, (Klettner et al., 2014) and new legal approaches that bring back concepts of fairness and equity to balance the recent over-reliance on economic rationality (Jacobs, 2012; Lydenberg, 2014).

\section{References}

Aggarwal, R., Erel, l., Ferreira, M. and Matos, P. (2011). 'Does governance travel around the world? Evidence from institutional investors', Journal of Financial Economics, 100, pp. 154-181.

Aguilera, R. and Cuervo-Cazurra, A. (2009). 'Codes of good governance', Corporate governance: an international review, 17, pp. 376-387.

Aguilera, R. V. (2005). 'Corporate governance and director accountability: An institutional comparative perspective', British Journal of Management. 16, pp. S39-S53.

Aguilera, R. V. and Crespi-Cladera, R. (2016). 'Global corporate governance: On the relevance of firms' ownership structure', Journal of World Business, 51, pp. 50-57.

Aguilera, R. V., Desender, K., Bednar, M. K. and Lee, J. H. (2015). 'Connecting the dots: Bringing external corporate governance into the corporate governance puzzle', The Academy of Management Annals, 9, pp. 483-573.

Arsalidou, D. (2012). 'Shareholders and corporate scrutiny: the role of the UK stewardship code', European company and financial law review, 9, pp. 342-379.

Barker, R. M. and Chiu, I. H.-Y. (2017). Corporate Governance and Investment Management: The Promises and Limitations of the New Financial Economy. Edward Elgar Publishing.

Bebchuk, L. A., Cohen, A. and Hirst, S. (2017). 'The agency problems of institutional investors', Journal of Economic Perspectives, 31, pp. 89-102.

Benford, R. D. and Snow, D. A. (2000). 'Framing processes and social movements: An overview and assessment', Annual review of sociology, 26, pp. 611-639.

Berle, A. A. and Means, G. G. C. (1932). The modern corporation and private property. Transaction publishers.

Çelik, S. and Isaksson, M. (2014). 'Institutional investors and ownership engagement', OECD Journal: Financial Market Trends, 2, pp. 93-114. 
Cheffins, B. R. (2010). 'The Stewardship Code's Achilles' Heel', The Modern Law Review, 73, pp. 1004-1025.

Chiu, I. H. (2012a). 'Institutional Shareholders as Stewards: Toward a new conception of corporate governance', Brooklyn Journal of Corporate, Financial \& Commercial Law, 6, pp. 2.

Chiu, I. H. (2012b). 'Stewardship as a force for governance: Critically assessing the aspirations and weaknesses of the UK Stewardship Code', European Company Law, 9 pp. 5.

Chiu, I. H. (2013). 'Reviving shareholder stewardship: critically examining the impact of corporate transparency reforms in the UK', Del. J. Corp. L., 38, pp. 983.

Chiu, I. and Katelouzou, D. (2016). 'From Shareholder Stewardship to Shareholder Duties: Is the Time Ripe?'. In Shareholder's Duties, Birkmose (ed), Kluwer Law International, Chapter 7.

Cicon, J. E., Ferris, S. P., Kammel, A. J. and Noronha, G. (2012). 'European corporate governance: a thematic analysis of national codes of governance', European financial management. 18 (4): 620-648.

Clarke, T. (2014). 'The impact of financialisation on international corporate governance: the role of agency theory and maximising shareholder value'. Law and Financial Markets Review, 8, pp. 39-51.

Collier, P. and Zaman, M. (2005). 'Convergence in European corporate governance: The audit committee concept', Corporate Governance: An International Review, 13, pp. 753-768.

Cuomo, F., Mallin, C. and Zattoni, A. (2016). 'Corporate governance codes: A review and research agenda', Corporate governance: an international review, 24, pp. 222-241.

Davis, G. F. (2008). 'A new finance capitalism? Mutual funds and ownership re-concentration in the United States', European Management Review, 5, pp. 11-21.

Davis, J. H., Schoorman, F. D. and Donaldson, L. (1997). 'Toward a stewardship theory of management', Academy of Management review, 22, pp. 20-47.

Daviter, F. (2007). 'Policy framing in the European Union', Journal of European Public Policy, 14, pp. 654-666.

De la Cruz, A., Medina, A. and Tang, Y. (2019). Ownership of Listed Companies Around the World. OECD.

Edmans, A. and Manso, G. (2011). 'Governance through trading and intervention: A theory of multiple blockholders', The Review of Financial Studies, 24, pp. 2395-2428.

Fama, E. F. and Jensen, M. C. (1983). 'Separation of ownership and control', The journal of law and Economics, 26, pp. 301-325.

Fichtner, J., Heemskerk, E. M. and Garcia-Bernardo, J. (2017). 'Hidden power of the Big Three? Passive index funds, re-concentration of corporate ownership, and new financial risk', Business and Politics, 19, pp. 298-326.

Fischer, F. (1995). Evaluating Public Policy. Nelson-Hall Publishers. 
Freeman, R. E., Wicks, A. C. and Parmar, B. (2004). 'Stakeholder theory and "the corporate objective revisited"', Organization science, 15, pp. 364-369.

Freshfields Bruckhaus Deringer (2005). A legal framework for the integration of environmental, social and governance issues into institutional investment. UNEP Finance Initiative.

Gillan, S. and Starks, L. T. (2003). 'Corporate governance, corporate ownership, and the role of institutional investors: A global perspective', Journal of applied Finance, 13.

Gilson, R. J. and Gordon, J. N. (2013). 'The agency costs of agency capitalism: Activist investors and the revaluation of governance rights', Columbia Law Review, 113, pp. 863-927.

Goranova, M., Dharwadkar, R. and Brandes, P. (2010). 'Owners on both sides of the deal: mergers and acquisitions and overlapping institutional ownership', Strategic Management Journal, 31, pp. 1114-1135.

Goto, G. (2018). 'The Logic and Limits of Stewardship Codes: The Case of Japan'. The University of Tokyo Business Law Working Paper Series.

Hawley, J. P. and Lukomnik, J. (2018). 'The third, system stage of corporate governance: Why institutional investors need to move beyond modern portfolio theory', Available at SSRN 3127767.

Hawley, J. P. and Williams, A. T. (2002). 'The universal owner's role in sustainable economic development', Corporate Environmental Strategy, 9, pp. 284-291.

Hawley, J. and Williams, A. (2000a). 'The emergence of universal owners: Some implications of institutional equity ownership', Challenge, 43, pp. 43-61.

Hawley, J. and Williams, A. (2000b). The rise of fiduciary capitalism: How institutional investors can make corporate America more democratic. University of Pennsylvania Press.

Haxhi, I. and Aguilera, R. V. (2012). 'Are codes fostering convergence in corporate governance? An institutional perspective'. In: The Convergence of Corporate Governance. Springer, pp. 234248.

Haxhi, I. and Van Ees, H. (2010). 'Explaining diversity in the worldwide diffusion of codes of good governance', Journal of international business studies, 41, pp. 710-726.

Hendry, J., Sanderson, P., Barker, R. and Roberts, J. (2006). 'Owners or traders? Conceptualizations of institutional investors and their relationship with corporate managers', Human Relations, 59, pp. 1101-1132.

Hernandez, M. (2008). 'Promoting stewardship behavior in organizations: A leadership model', Journal of Business Ethics, 80, pp. 121-128.

Heugens, P. P. and Otten, J. A. (2007). 'Beyond the dichotomous worlds hypothesis: Towards a plurality of corporate governance logics', Corporate governance: An international review, 15, pp. 1288-1300.

Hill, J. G. (2017). 'Good Activist/Bad Activist: The Rise of International Stewardship Codes', Seattle University Law Review, 41, pp. 497. 
Hirschman, A. O. (1970). Exit, voice, and loyalty: Responses to decline in firms, organizations, and states. Harvard university press.

Isabella, L. A. (1990). 'Evolving interpretations as a change unfolds: How managers construe key organizational events', Academy of Management journal, 3, pp. 7-41.

Jacobs, J. B. (2012). 'Does the new corporate shareholder profile call for a new corporate law paradigm', Fordham J. Corp. \& Fin. L., 18, pp. 19.

Jahnke, P. (2019). 'Ownership concentration and institutional investors' governance through voice and exit', Business and Politics, 21, pp. 327-350.

Jamali, D., Safieddine, A. M. and Rabbath, M. (2008). 'Corporate governance and corporate social responsibility synergies and interrelationships', Corporate Governance: An International Review, 16, pp. 443-459.

Jensen, M. C. (2002). 'Value maximization, stakeholder theory, and the corporate objective function', Business ethics quarterly, 12, pp. 235-256.

Jensen, M. C. and Meckling, W. H. (1976). 'Theory of the firm: Managerial behavior, agency costs and ownership structure', Journal of financial economics, 3, pp. 305-360.

Johnson, R. A., Schnatterly, K., Johnson, S. G. and Chiu, S.-C. (2010). 'Institutional investors and institutional environment: A comparative analysis and review', Journal of Management Studies, 47, pp. 1590-1613.

Juravle, C. and Lewis, A. (2008). 'Identifying impediments to SRI in Europe: a review of the practitioner and academic literature', Business Ethics: A European Review, 17, pp. 285-310.

Kahle, K. M. and Stulz, R. M. (2017). 'Is the US public corporation in trouble?', Journal of Economic Perspectives, 31, pp. 67-88.

Katelouzou, D. and Klettner, A. (2020). 'Sustainable Finance and Stewardship: Unlocking Stewardship's Sustainability Potential'. In Global Shareholder Stewardship: Complexities, Challenges and Possibilities, Cambridge University Press, forthcoming.

Kay, J. (2012). The Kay Review of UK Equity Markets and Long-Term Decision Making.

Keay, A. (2012). The enlightened shareholder value principle and corporate governance. Routledge.

Keay, A. (2014). 'Comply or explain in corporate governance codes: in need of greater regulatory oversight?: Comply or explain in corporate governance codes', Legal Studies, 34, pp. 279304.

Keay, A. (2011). 'Moving Towards Stakeholderism? Enlightened Shareholder Value, Constituency Statutes and More: Much Ado About Little?', European Business Law Review, 22, pp. 1-49.

Kiernan, M. J. (2007). 'Universal Owners and ESG: leaving money on the table?', Corporate Governance: An International Review, 15, pp. 478-85.

Klettner, A., Clarke, T. and Boersma, M. (2014). 'The governance of corporate sustainability: Empirical insights into the development, leadership and implementation of responsible business strategy', Journal of business ethics, 122, pp. 145-165. 
Klettner, A. L. (2017). 'The impact of stewardship codes on corporate governance and sustainability', New Zealand Business Law Quarterly, 23, pp. 259-275.

Klüver, H., Mahoney, C. and Opper, M. (2015). 'Framing in context: how interest groups employ framing to lobby the European Commission', Journal of European Public Policy, 22, pp. 481498.

Lydenberg, S. (2007). 'Universal Investors and Socially Responsible Investors: a tale of emerging affinities', Corporate Governance: An International Review, 15, pp. 467-77.

Lydenberg, S. (2014). 'Reason, rationality, and fiduciary duty', Journal of business ethics, 119, pp. 365-380.

Majoch, A. A., Hoepner, A. G. and Hebb, T. (2017). 'Sources of stakeholder salience in the responsible investment movement: why do investors sign the principles for responsible investment?', Journal of business ethics, 140, pp. 723-741.

McNulty, T. and Nordberg, D. (2016). 'Ownership, activism and engagement: Institutional investors as active owners', Corporate Governance: An International Review, 24, pp. 346-358.

Mees, B. and Smith, S. A. (2019). 'Corporate governance reform in Australia: a new institutional approach', British Journal of Management, 30, pp. 75-89.

Micheler, E. (2013). 'Facilitating Investor Engagement and Stewardship', European Business Organization Law Review, 14, pp. 29-56.

Mitchell, R. K., Agle, B. R. and Wood, D. J. (1997). 'Toward a theory of stakeholder identification and salience: Defining the principle of who and what really counts', Academy of management review, 22, pp. 853-886.

Naqvi, M. (2019). Sustainability in South Africa The Swing from SRI to ESG / S\&P Global. 23 July 2019.

OECD (2011). The Role of Institutional Investors in Promoting Good Corporate Governance. OECD.

Office for National Statistics (2020). Ownership of UK quoted shares: 2018. Office for National Statistics.

Otsuka, A. (2018). 'For Institutional Investors, the Alternative of Exit Or Voice, Or Empowerment Or Engagement in the United States and the United Kingdom', Int'l Comp., Policy \& Ethics Law. Review, 2, pp. 673.

PRI (2015). Fiduciary Duty in the 21st Century. PRI.

Queen, P. E. (2015). 'Enlightened shareholder maximization: is this strategy achievable?', Journal of Business Ethics, 127, pp. 683-694.

Raelin, J. D. and Bondy, K. (2013). 'Putting the Good Back in Good Corporate Governance: The Presence and Problems of Double-Layered Agency Theory', Corporate Governance: An International Review, 21, pp. 420-35.

Reisberg, A. (2015). 'The UK Stewardship Code: On the Road to Nowhere?', Journal of Corporate Law Studies, 15, pp. 217-253. 
Richardson, B. J. (2009). 'Keeping ethical investment ethical: Regulatory issues for investing for sustainability', Journal of Business Ethics. 87, pp. 555-572.

Roach, L. (2011). 'The UK Stewardship Code', Journal of Corporate Law Studies, 11, pp. 463-493.

Ryan, L. V. and Schneider, M. (2002). 'The antecedents of institutional investor activism'. Academy of Management Review, 27, pp. 554-573.

Ryan, L. V. and Schneider, M. (2003). 'Institutional investor power and heterogeneity: Implications for agency and stakeholder theories', Business \& Society, 42, pp. 398-429.

Sandberg, J. (2011). 'Socially responsible investment and fiduciary duty: Putting the freshfields report into perspective', Journal of Business Ethics, 101, pp. 143-162.

Sandberg, J. (2013). '(Re-)Interpreting Fiduciary Duty to Justify Socially Responsible Investment for Pension Funds?', Corporate Governance: An International Review, 21, pp. 436-46.

Schreier, M. (2013). 'Qualitative Content Analysis'. In: The SAGE Handbook of Qualitative Data Analysis. SAGE.

Sparkes, R. and Cowton, C. J. (2004). 'The maturing of socially responsible investment: A review of the developing link with corporate social responsibility', Journal of Business Ethics, 52, pp. $45-57$.

SSE (2019). SSE, IFC, Kenya CMA and Nairobi Stock Exchange are building momentum for more sustainable capital markets- at home and abroad / Sustainable Stock Exchanges. 4 March 2019.

Stathopoulos, K. and Voulgaris, G. (2016). 'The impact of investor horizon on say-on-pay voting', British Journal of Management, 27, pp. 796-818.

Tilba, A. and McNulty, T. (2013). 'Engaged versus Disengaged Ownership: The Case of Pension Funds in the UK', Corporate Governance: An International Review, 21, pp. 165-82.

Tricker, B. (1998). 'The role of the institutional investor in corporate governance', Corporate Governance: An International Review, 6, pp. 213-216.

Useem, M. (1996). Investor capitalism: How money managers are changing the face of corporate America. New York: Basic Books.

Veldman, J. and Willmott, H. (2016). 'The cultural grammar of governance: The UK Code of Corporate Governance, reflexivity, and the limits of 'soft'regulation', Human Relations, 69, pp. 581-603.

Wheeler, S. (2013). From Responsible Saver to Stewarded Investor?. In Feenan D. (ed) Exploring the 'Socio of Socio-Legal Studies, Palgrave Macmillan, London.

Yanow, D. (2000). Conducting Interpretive Policy Analysis. SAGE.

Zattoni, A. and Cuomo, F. (2008). 'Why adopt codes of good governance? A comparison of institutional and efficiency perspectives', Corporate governance: an international review, 16, pp. 1-15. 
Zattoni, A. and Cuomo, F. (2010). 'How independent, competent and incentivized should nonexecutive directors be? An empirical investigation of good governance codes', British Journal of Management, 21, pp. 63-79.

Zembrowski, P. (2019). Thailand Leads the Region in ESG Disclosures / CFA Institute Market Integrity Insights. 12 June 2019. 